\title{
Delayed Elastic Strain and Set-recovery Evaluation in High-pressure Densified Hybrid Poplar Wood - New Assessment Considerations
}

\author{
Kaiya Yan, ${ }^{\text {a,b }}$ Fengming Zhang, ${ }^{\mathrm{a}, \mathrm{b}}$ Yang Du, ${ }^{\mathrm{a}, \mathrm{b}}$ Hosahalli S. Ramaswamy, ${ }^{\mathrm{c}}$ \\ Songming Zhu, ${ }^{\mathrm{a}, \mathrm{b}}$ Lihui $\mathrm{Hu}^{\mathrm{a}, \mathrm{b}}$ and Yong $\mathrm{Yu}^{\mathrm{a}, \mathrm{b}, *}$
}

\begin{abstract}
The deformation behavior of high-pressure (HP)-treated hybrid poplar wood, the subsequent swelling, and the equilibrium moisture content properties of HP-densified wood were evaluated using a modified delayed strain/set-recovery method of cyclic humidification-dehumidification at different relative humidity $(\mathrm{RH})$ conditions. The HP treatment resulted in significant compression (densification) of the wood under different treatment conditions. For treated wood samples, the value of delayed elastic strain was relatively small when stored at $20^{\circ} \mathrm{C}$ and $65 \% \mathrm{RH}$, which indicated that HP-densified wood possessed dimensional stability. The HP-compressed poplar yielded lower equilibrium moisture content than the control at low $\mathrm{RH}$, while major increases were observed at high $\mathrm{RH}$ above $76 \%$. Marginal of thickness swelling was observed under the cyclic humidification-dehumidification method in the low $\mathrm{RH}$ range while significant swelling occurred at high $\mathrm{RH}$. Conventional methods would only show results that were appropriate for storage at high $\mathrm{RH}$ environments. The $\mathrm{RH}$ threshold for set-recovery of HP-compressed wood was between $33 \%$ and $54 \%$ for optimal use, and the extent of set-recovery increased rapidly when $\mathrm{RH}$ was between $85 \%$ and $95 \%$. Such differences could not be recognized with the conventional methods. In addition, the prolonged holding time significantly decreased the $\mathrm{RH}$ threshold value $(\mathrm{P}<0.05)$.
\end{abstract}

Keywords: High-pressure treatment; Hybrid poplar; Delayed elastic strain; Set-recovery; Humid-dry cycles; Microstructure

Contact information: a: College of Biosystems Engineering and Food Science, Zhejiang University, 866 Yuhangtang Road, Hangzhou 310058, China; b: Key Laboratory of Equipment and Informatization in Environment Controlled Agriculture, Ministry of Agriculture, 866 Yuhangtang Road, Hangzhou, 310058, China; c: Department of Food Science and Agricultural Chemistry, McGill University, St-Anne-deBellevue, Quebe, Canada; *Corresponding author: yyuzju@zju.edu.cn

\section{INTRODUCTION}

High-density wood is an important structural and decorative material that is widely used for many common applications. More importantly, wood is the only renewable and sustainable material among four major building materials: steel, cement, lumber, and plastic. In recent years, wood-based products have become increasingly popular because of their high strength-to-weight ratio, comfortable texture, aesthetic grain appearance patterns, as well as environmental and ecological characteristics. However, due to its slow and long growing period, the supply of such high-density wood is very limited, which leads to increased demand for these products in the market. Although still considered to be insufficient to fully meet the market demand, there is an abundant supply of soft and low density wood that can be grown more rapidly should the need arise. Their main 
disadvantage is that they are soft and have poor mechanical strength. To improve their density and mechanical strength, various densification methods have been developed (Navi and Heger 2004; Kutnar et al. 2009; Fang et al. 2012; Gao et al. 2016; Yu et al. 2017). Among these, the eco-friendly high-pressure (HP) densification method seems to be a more promising option. HP treatment is a non-thermal food processing method. Our research team applied this technology into wood modification and have obtained many research achievements recently. The HP densification method does not require long processing time and can achieve better effect compared with traditional thermal wet compression techniques. (Zhu et al. 2017; Yu et al. 2017, 2018; Li et al. 2018).

Wood is a viscoelastic material and the deformation (strain) induced by compression (stress) of wood can result in one or more of the following three strains: plastic strain, elastic strain, or delayed elastic strain (Blomberg 2005). During compression, the elastic strain energy is stored in the microfibril matrix, causing an internal stress, which bounces back upon the stress release, making the densified wood revert partially or fully to its original state. For truly elastic material under stress, the elastic strain disappears once the pressure is released, and the material regains its shape immediately after the stress release. However, the delayed elastic strain is a slow recovery process either fully or partially depending on the recovery time and condition after the stress release. The plastic strain of densified wood is considered metastable. Without any post-treatment, such deformation stays relatively stable (plastic), except when the densified wood is wet, exposed to a high humidity environment, or heated. The delayed elastic strain is an important indicator of the dimensional stability of densified wood and is a parameter needed for its successful use in many applications (Blomberg et al. 2006; Laine et al. 2016). Dimension instability is an obvious critical problem for the usability of densified wood products. Many post compression treatments have been developed for the densified wood to completely resist changes from the plastic deformation in harsh environments (Navi and Heger 2004; Laine et al. 2016). These additional treatments require time, energy, and cost, and result in low productivity and limited industrialization of compression technologies.

However, not all wood products are required to be placed in severe environments causing dimensional instability (e.g., placing in rain, soaking in water, or used in very high relative humidity environmental conditions). The standards for measuring set-recovery of compressed wood products have not been developed based on the real end-use conditions. The common techniques make use of water-soaking, soaking-drying cycles, and soaking in hot water (Laine et al. 2013a). These measuring methods do not provide data that are appropriate for many realistic end-use conditions for densified wood. For example, indoor wooden products are stored in a moderate relative humidity $(\mathrm{RH})$ environment, and therefore they do not need to possess high dimension stabilities as needed in a wet area or those used in water-soaking tests. These indoor wood products are perhaps cycled through mild humidification-drying cycles at comfort zone $\mathrm{RH}$ conditions (25 to 45\%). Dimensional stability for such applications should be based on tests that expose the wood to such conditions rather than wetting. Therefore, testing conditions need to be modified for such applications to provide better set-recovery parameters.

The objective of this study was to develop a method for the delayed elastic strain and set-recovery of HP-densified poplar wood at different RH environments under a cyclic humidification-dehumidification process. Furthermore, this work studies the influence of HP process parameters (compression pressure and pressure holding time) on the dimensional stability of HP-densified wood under such conditions. 


\section{EXPERIMENTAL}

\section{Materials}

The wood material used for the study was hybrid poplar (Populus $\times$ Euramericana Neva.), obtained from a plantation forest in Henan Province, China. Prior to experiments, cut samples of wood with the dimensions of $180 \times 80 \times 30 \mathrm{~mm}^{3}$ (longitudinal $\times$ tangential $\times$ radial) were sawn from these poplar boards, and they were conditioned using climate regulating equipment (HWS-280; Ningbo Jiangnan Instrument Plant, Ningbo, China) at 20 ${ }^{\circ} \mathrm{C}$ and $65 \% \mathrm{RH}$ for slow air drying and equilibration. The moisture content and density of the hybrid poplar specimens were $11.8 \pm 1 \%$ and $0.376 \pm 0.031 \mathrm{~g} / \mathrm{cm}^{3}$, respectively.

\section{Methods}

HP densification treatment

The HP treatment was performed in a laboratory-scale HP equipment (UHPF-750; Baotou Kefa High Pressure Technology Co., Baotou, China) with a maximum volume of $5 \mathrm{~L}$ and $600 \mathrm{MPa}$ pressure limit. The average pressure increase rate was approximately 100 $\mathrm{MPa} / 60 \mathrm{~s}$ and depressurization rate was approximately $100 \mathrm{MPa} / \mathrm{s}$. For every $100 \mathrm{MPa}$ rise in pressure, the temperature increased by $3{ }^{\circ} \mathrm{C}$

The poplar samples were fixed by steel plates on both sides to obtain uniform compression and vacuum-packaged using a vacuum packaging machine (Shanghai Yute Packaging Machinery Manufacturing Co., Ltd., Shanghai, China) to prevent the contact between water and wood. The packaged samples were placed in the HP chamber for HP treatment.

Different HP treatment pressure level (50, 100, 150, and $200 \mathrm{MPa})$ and pressure holding time $(0,30,60$, and $300 \mathrm{~s})$ were employed in this study. $0 \mathrm{~s}$ holding time represented a pressure pulse: immediately pressure release after the target pressure was reached. The untreated sample (without HP treatment) was the control group. All experiments were repeated three times.

\section{Compression ratio test}

The compression ratio $(\mathrm{CR})$ of the wood sample in the thickness direction was measured using Eq. 1, where $T_{\mathrm{o}}$ and $T_{\mathrm{c}}$ are the thickness of specimens ( $\mathrm{mm}$ ) before and immediately after densification, respectively:

$$
\text { Compression ratio }(\%)=\frac{T_{o}-T_{C}}{T_{o}} \times 100
$$

\section{Delayed elastic strain}

Wood samples were conditioned at $20{ }^{\circ} \mathrm{C}$ and $65 \% \mathrm{RH}$ after the HP densification treatment. Thicknesses were recorded at 0, 1, 24, 48, 72, 96, 120, 144, and $168 \mathrm{~h}$. Delayed elastic strain (DES) was calculated using Eq. 2, where $T_{\mathrm{d}}$ is the thickness (mm) at different times.

$$
\text { Delayed elastic strain }(\%)=\frac{T_{d}-T_{C}}{T_{o}-T_{C}} \times 100
$$




\section{Equilibrium moisture content}

Saturated inorganic salt solutions were used to maintain different constant equilibrium relative humidity (Yu et al. 2015). Climate chambers with selected RH 33.1, $54.4,68.3,75.5,85.1$, and $94.6 \%$ were maintained using specific saturated inorganic salt solutions, as indicated in (Table 1) in a closed environment at $20{ }^{\circ} \mathrm{C}$. The apparatus regulating $\mathrm{RH}$ is illustrated in Fig. 1 in which a welded wire mesh basket was suspended from the middle of the plug in a hermetically sealed glass jar and then placed in a temperature-controlled incubator to reach equilibrium conditions.

Table 1. Equilibrium Relative Humidity Values Provided by Different Saturated Salt Solutions at $20^{\circ} \mathrm{C}$

\begin{tabular}{|c|c|c|c|c|c|c|}
\hline & $\mathrm{MgCl}_{2}$ & $\mathrm{Mg}\left(\mathrm{NO}_{3}\right)_{2}$ & $\mathrm{CuCl}$ & $\mathrm{NaCl}$ & $\mathrm{KCl}$ & $\mathrm{KNO}_{3}$ \\
\hline $20{ }^{\circ} \mathrm{C}$ & $33.1 \%$ & $54.4 \%$ & $68.3 \%$ & $75.5 \%$ & $85.1 \%$ & $94.6 \%$ \\
\hline
\end{tabular}

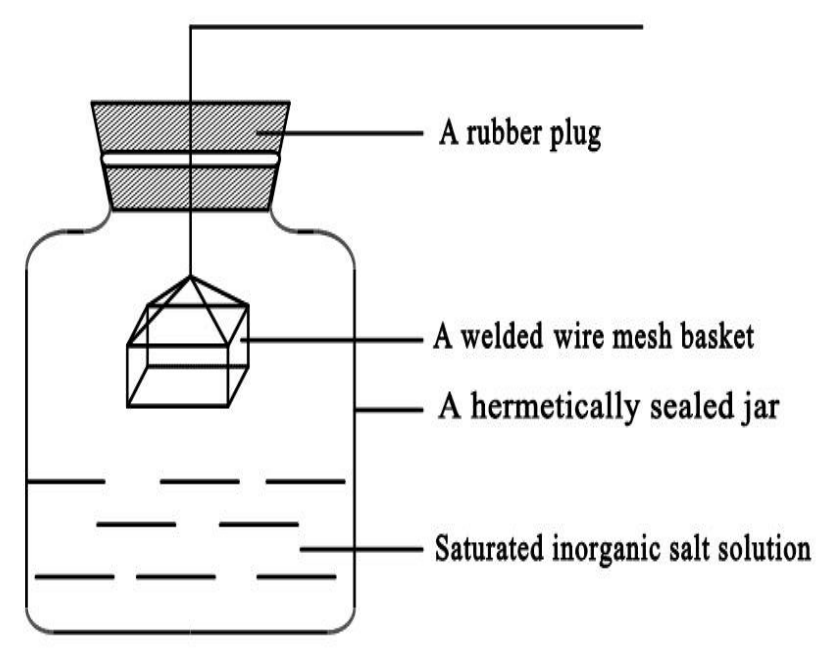

Fig. 1. Apparatus for determining the equilibrium moisture content of poplar wood samples

First, poplar specimens were placed in a drying oven $\left(103 \pm 2{ }^{\circ} \mathrm{C}\right)$ for $12 \mathrm{~h}$ until they reached a constant weight (oven drying). During the adsorption experiment, the ovendry poplar specimens were placed in a welded wire mesh basket (as shown in Fig. 1). A static gravimetric method was used in this study to determine equilibrium moisture content (EMC) of poplar wood samples according to Eq. 3. Samples were weighed every two days until the change in mass was negligible (less than $0.0050 \mathrm{~g}$ ),

$$
\text { Equilibrium moisture content }(\%)=\frac{m_{1}-m_{0}}{m_{0}} \times 100
$$

where here $m_{0}$ is the oven-dry mass $(\mathrm{g})$ of poplar sample and $m_{1}$ is the mass $(\mathrm{g})$ of polar sample that reached equilibrium humid condition.

\section{Thickness swelling}

For this test, the dimensional change of HP-treated wood was evaluated under the six different $\mathrm{RH}$ conditions (Table 1). Test samples prepared for HP densification were cut into $10 \times 10 \times 10 \mathrm{~mm}^{3}$ size and placed in the oven at $103{ }^{\circ} \mathrm{C}$ oven for $12 \mathrm{~h}$ until poplar specimens reached oven-dry condition, and then placed in one of the six different RH 
conditions of $33 \%$ to $95 \%$ until consistent thickness. Then, wood specimens were again oven dried again at $103{ }^{\circ} \mathrm{C}$ for $12 \mathrm{~h}$ for the irreversible swelling test. The thickness swelling efficiency was calculated according Eq. 4,

$$
\text { Thickness swelling efficiency }(\%)=\frac{t_{1}-t_{0}}{t_{0}} \times 100
$$

where $t_{\mathrm{o}}$ and $t_{1}$ are the thicknesses $(\mathrm{mm})$ in oven-dried condition before and after the humidify-condition test

\section{Irreversible swelling}

Irreversible swelling, as proposed by Gabrielli and Kamke (2010), is an important indicator to measure dimensional stability of wood. It was obtained as in the preceding section and calculated according to Eq. 5,

$$
\text { Irreversible swelling }(\%)=\frac{V_{O D 1}-V_{O D 0}}{V_{S}-V_{O D 0}} \times 100
$$

where $V_{\mathrm{OD} 0}$ is the original volume $\left(\mathrm{mm}^{3}\right)$ in oven-dried condition after HP treatment, $V_{\mathrm{S}}$ is the volume $\left(\mathrm{mm}^{3}\right)$ after the humidify-condition test described in thickness swelling test, and $V_{\mathrm{OD} 1}$ is the volume $\left(\mathrm{mm}^{3}\right)$ in oven-dried condition after the humidity condition test.

\section{Statistical Analysis}

Statistical differences among all tested wood specimens were analyzed using SPSS (version 20.0, IBM Corporation, Armonk, NY, USA) following the one-way analysis of variance (One-way ANOVA). Duncan's multiple range tests at a significance level of 0.05 were conducted. Results were presented as the mean values with standard deviations (SD). Different letters were used to indicate significance of differences, and the significance level was marked according to alphabetical order. Graphic presentations were obtained using the Origin 8.0 (Origin Lab, USA).

\section{RESULTS AND DISCUSSION}

\section{Effect of HP on Compression Ratio}

As expected, HP densification resulted in varied size reductions in poplar wood samples as influenced by the severity of the HP treatment (Fig. 2). The reduction in the thickness of the wood was represented by the $\mathrm{CR}$ with a higher compression ratio indicating higher compaction, greater reduction in volume, and reduced thickness. As shown in Fig. 2, poplar wood specimens clearly demonstrated that HP treatment resulted in an increase in CR with pressure. The majority of compression deformation $(\mathrm{CR}>50 \%)$ occurred at even the lowest treatment pressure level used (50 MPa), and only small increments in compression deformation resulted at higher pressures (100 to $200 \mathrm{MPa}$ ). Similar results were found in earlier studies (Trenard 1977; Blomberg and Persson 2004). Ahmed et al. (2013) reported that the compression deformation of wood was affected by its anatomical features. A thinner cell wall (or a larger cell lumen of wood) resulted in larger deformation. The vessels of hybrid poplar, with a relatively thin cell wall and large cell lumen, could therefore be easily collapsed, even at low pressure levels. That is why the major compaction occurred below $50 \mathrm{MPa}$ with little improvement thereafter at higher pressures. Liu et al. (1995) also found a similar stress-strain relationship in the large transverse compression deformation test. They stated that the stress-strain relationship of 
wood changes after the cell cavity is collapsed (the critical point of cell wall densification), and that the stress required for the same strain increases exponentially. Zhang et al. (2010a) pointed out that the compression deformation of wood is determined by the change in its molecular distance when the poplar sample is compacted into a substantive substance.

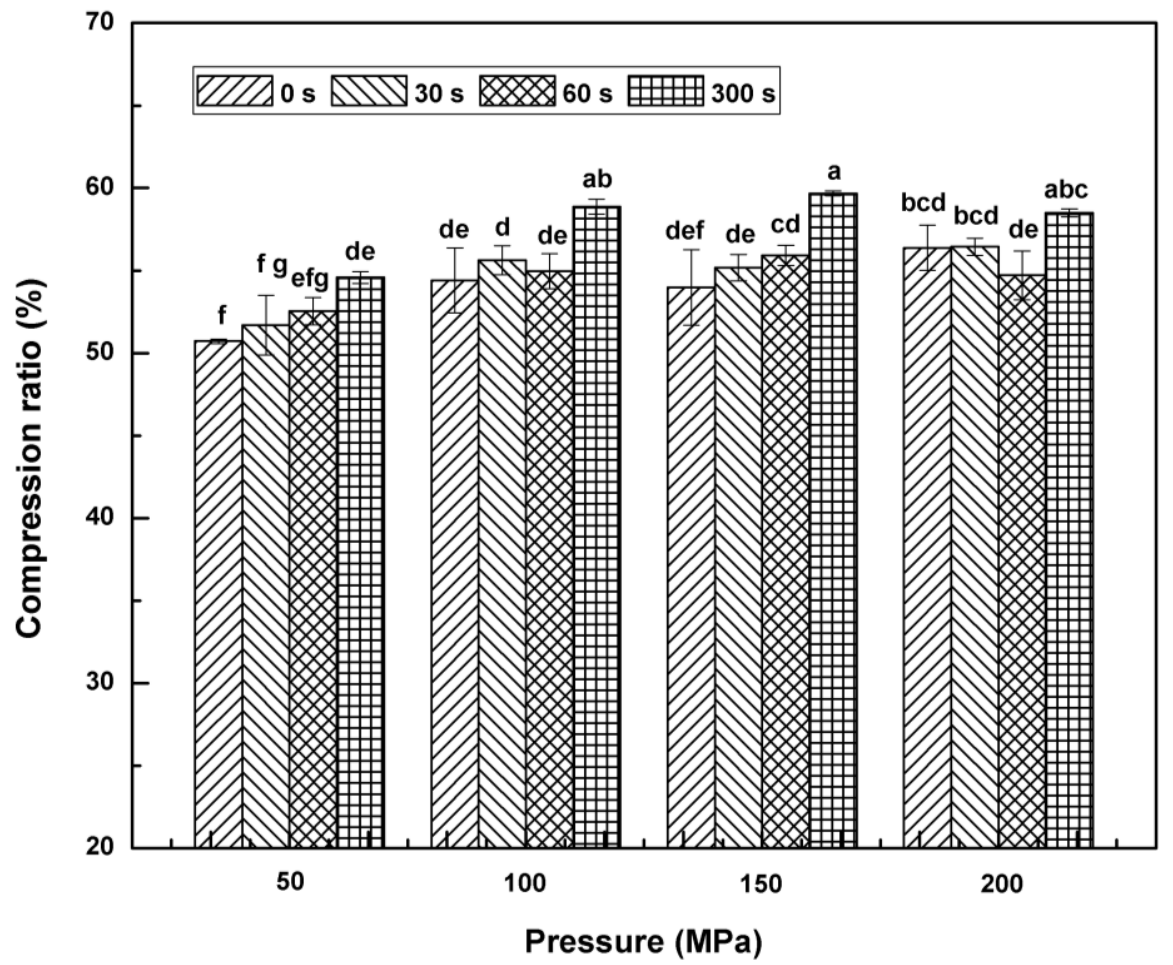

Fig. 2. CR of HP-treated poplar under various conditions; the error bars indicate the standard deviation and different letters above the columns indicate significant differences $(P<0.05)$

Furthermore, in addition to the influence of pressure level, CR also increased slightly with the holding time at each pressure level. Although there was no significant difference between holding times of 0 to $60 \mathrm{~s}$, the intensification of compaction became significant and clearly noticeable once the $300 \mathrm{~s}$ holding time treatment was included in the group. This may be related to the viscoelastic properties of solid materials, and the prolonged holding time resulting in the creep effect of wood under continued exposure to constant external pressure (Kutnar and Kamke 2012).

\section{Effect of HP Densification on Delayed Elastic Strain}

Results of DES of poplar samples treated under various conditions are shown in Fig. 3. Wood is a type of viscoelastic material, and therefore the cell deformations caused by the densification can result in internal stresses stored in the microfibril matrix, which might lead to the partial spring-back of densified wood after the pressure release. A previous study (Yu et al. 2017) also demonstrated that thickness of the densified woods changed with storage time. In addition, there was no significant difference $(P>0.05)$ in the DES among HP-densified specimens (except $50 \mathrm{MPa}, 30 \mathrm{~s}$ ), which indicated that the holding time and pressure level had no effect on the DES of compressed wood, when determined at $20{ }^{\circ} \mathrm{C}$ and $65 \% \mathrm{RH}$. All the subsequent experiments were conducted after the DES swelling test. 


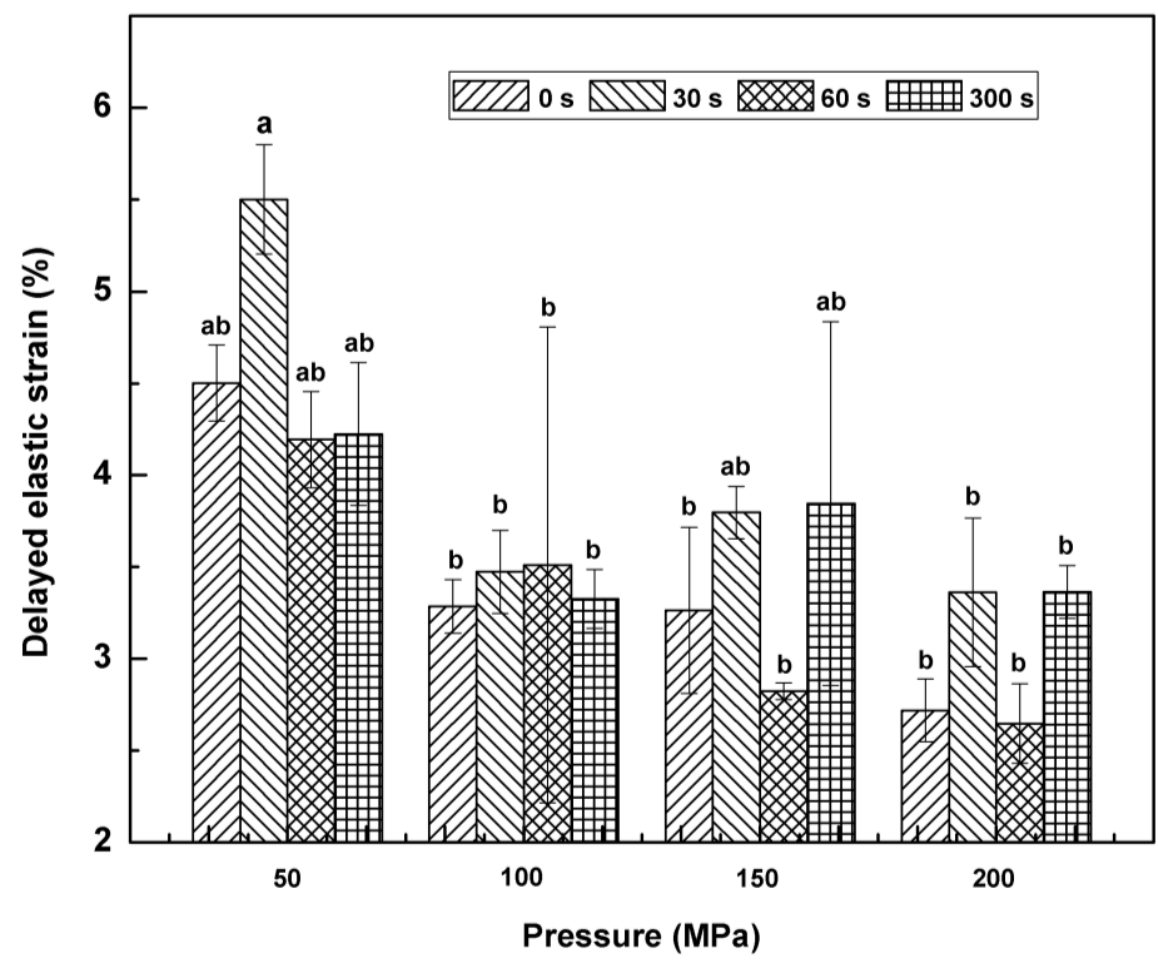

Fig. 3. DES of poplar treated under various conditions; the error bars indicate the standard deviation and different letters above the columns indicate significant differences $(P<0.05)$

\section{Effect of HP Densification on Equilibrium Moisture Content}

Figure 4 shows the EMC of HP-treated and untreated poplar at $20^{\circ} \mathrm{C}$ as related to storage at different $\mathrm{RH}$ ranging from $33 \%$ to $95 \%$. The EMC of densified samples changed with RH, and all EMC-RH (moisture sorption isotherm, MSI) curves of test samples were in-line with the typical MSI of wood. In the RH range of $33 \%$ to $68 \%$, EMC of poplar specimens of HP-treated wood at different pressure levels increased linearly with increasing $\mathrm{RH}$, while beyond $65 \%$, the extent of EMC appeared to increase more exponentially as previously observed by Ding et al. (2015).

At the same environmental RH, the difference in EMC of poplar samples treated at different pressure levels was small. The EMC's value of densified samples fluctuated within a small range of 4.86 to $5.94 \%(33 \% \mathrm{RH}), 8.19$ to $9.12 \%(54 \% \mathrm{RH}), 10.39$ to $11.42 \%$ (68\% RH), 13.11 to $14.47 \%$ ( $76 \% \mathrm{RH}), 15.61$ to $17.26 \%(85 \% \mathrm{RH})$, and 21.22 to $24.58 \%$ (95\% RH). There was no patterned change among different HP treatments, which indicated that pressure or holding time had little effect on the EMC of poplar. The difference in EMC's value above may have been due to normal variability associated with in poplar. 

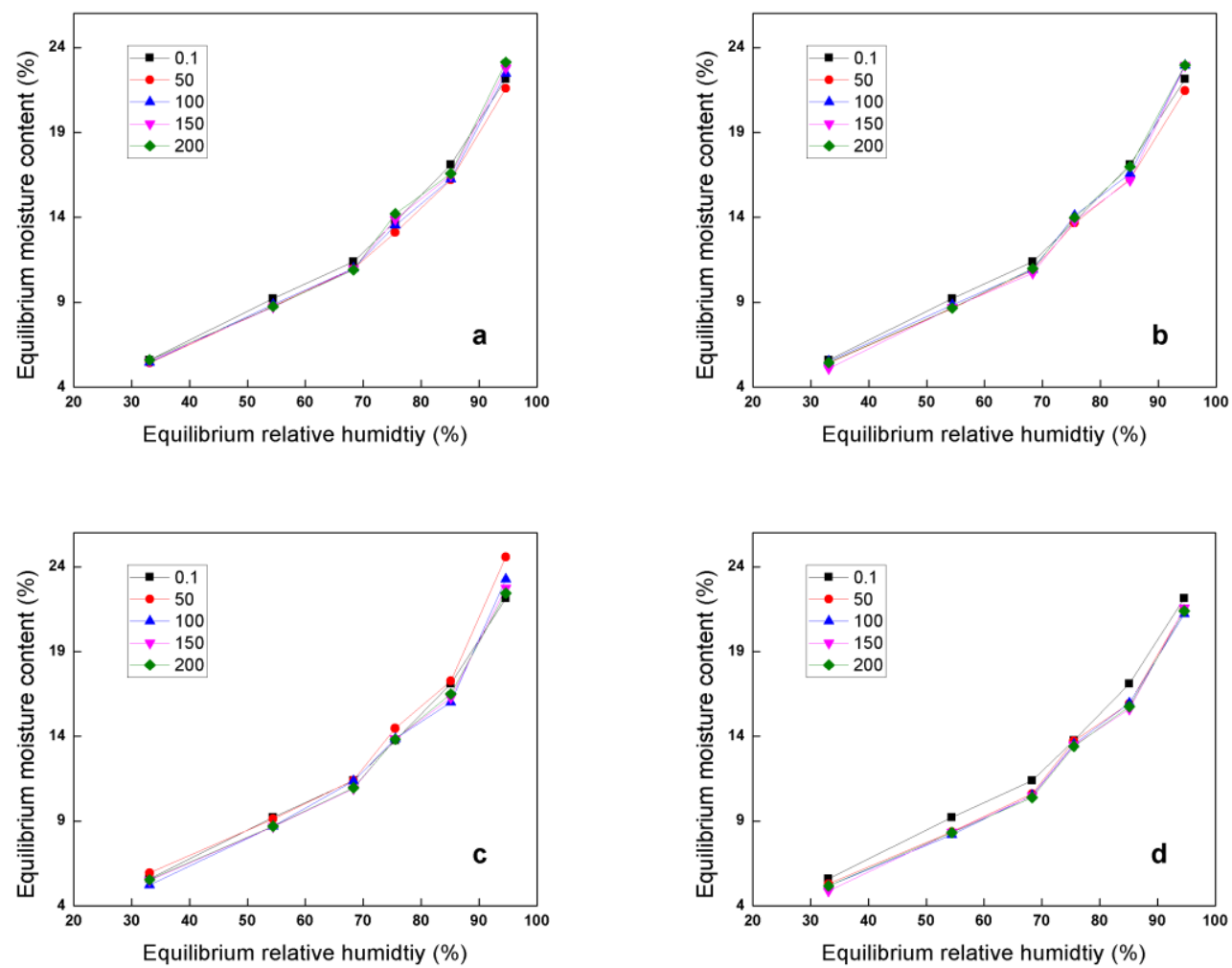

Fig. 4. EMC of poplar treated under various conditions; letters on the picture indicate holding time: a (0 s), b (30 s), c (60 s), and d (300 s)

Figure 4(d) reveals that during storage at $\mathrm{RH}$ ranging between $33 \%$ and $68 \%$, the control wood samples yielded a higher EMC than all HP-treated samples. However, there were no significant differences between EMCs of untreated and HP-treated samples ( $\mathrm{p}>$ 0.05 ) when the $\mathrm{RH}$ was above $76 \%$. This may have been related to the swelling characteristics of wood material. The authors' previous studies have shown that at an environmental RH from $33.1 \%$ to $75.5 \%$ the HP-treated Paulownia wood samples had comparatively lower EMC values than the control samples (Yu et al. 2018; Jiang et al. 2018). This is consistent with the present study. Compared with 0, 30, and $60 \mathrm{~s}$ HP holding time, the longer holding time $(300 \mathrm{~s})$ treatment resulted in denser wood. High environmental RH resulted in volume expansion of the poplar specimens, particularly denser HP-treated samples. The HP-treated samples had a small amount of expansion at lower environmental RH, and their structures were still denser, which impeded the penetration of water molecules. However, at higher environmental RH, the volume of HPdensified wood almost recovered to the pre-compression state, so that more voids and channels for water in and out appeared inside.

\section{HP Densification and Its Effect on Thickness Swelling Efficiency}

Below the fiber saturation point, changes in the moisture content of wood resulted in deformations, such as shrinkage or swelling. The thickness swelling efficiency (TSE) is used to analyze the progress of swelling as compared to the thickness in the oven-dry state (before moisture absorption/soaking test), and is an important indicator of the dimensional 
stability of wood during variations in storage RH. The TSE of HP-treated and untreated poplar at different RH (33 to 95.5\%) are shown in Table 1. The TSE of the control sample increased with an increase in $\mathrm{RH}$, which was due to the normal water absorption/swelling characteristic of wood. The wood continued to adsorb water when RH increased. Because water molecules are attracted by the hydrophilic groups of cellulose and hemicellulose to form hydrogen bonds, the spacing of cellulose molecules is enlarged and causes the cell wall expansion.

Compared with the control, HP-treated samples had a significant influence on the dimensional stability of the poplar. The TSE values in the thickness direction increased from $1.38 \%$ (control) to 6.06 to $7.73 \%$ at $33 \% \mathrm{RH}, 2.02 \%$ to 13.3 to $16.8 \%$ at $54 \% \mathrm{RH}$, $1.74 \%$ to 18.5 to $24.3 \%$ at $68 \% \mathrm{RH}, 2.33 \%$ to 26.7 to $36.8 \%$ at $76 \% \mathrm{RH}, 3.40 \%$ to 37.6 to $45.4 \%$ at $85 \% \mathrm{RH}$, and form $4.47 \%$ to 57.4 to $83.5 \%$ at $95 \% \mathrm{RH}$ after HP densification treatment. In addition, the difference between control and HP-treated samples enlarged with an increase in $\mathrm{RH}$, and the maximum difference value reached $79 \%$ at $95 \% \mathrm{RH}$. The shrinkage and expansion properties of wood are related to its cell walls. The natural swelling of wood after compression treatment has been observed in previous study (Mantanis et al. 1994). Skyba et al. (2009) reported that densified wood usually reverts to the uncompressed condition at high RH, which results in a higher TSE change than in the control. As shown in Table 2, the change in the TSE of HP-densified poplar was more complex. There were no clear patterns in the TSE among all HP-treated poplars stored at RH 33\% and 54\%, while there were no significant differences at higher RH, except for 50 $\mathrm{MPa}-0 \mathrm{~s}, 50 \mathrm{MPa}-30 \mathrm{~s}$, and $100 \mathrm{MPa}-0 \mathrm{~s}$. The phenomenon above may have been caused by the following factors. The shape of densified wood is usually distorted after swelling or shrinking, which affects the consistency and accuracy of data measurement (Laine et al. 2013). It was demonstrated that natural pozzolans can be used for stabilization of marl soil due to their similar structure and the increase in the contents of volcanic ash decrease the expansion and ductility of marl soil (Bahadori et al. 2018, 2019a,b). This provides research reference for the following studies on wood shrinkage and swelling. When storage $\mathrm{RH}$ is low, the expansion of the HP-treated sample is small, which leads to larger relative errors that mask the changing tendency of TSE with pressure or holding time. In addition, the densified wood usually reverts to original shape at high $\mathrm{RH}$, which cause high irreversible deformation that can be much larger than the natural swelling of wood caused by moisture absorption. Therefore, the results above only showed the HP-compressed poplar underwent obvious deformation recovery at $68 \% \mathrm{RH}$.

Between the first and second humidify-dry cycle, there were no significant differences in the trend for TSE, although they increased gradually with increasing RH. For example, with $100 \mathrm{MPa}-60 \mathrm{~s}$ the increases in TSE were $0.37,0.76,3.84,4.52$, 7.01, and 6.73\%, respectively, after repeated humidity cycles at $33,54,68,76,85$, and $95 \% \mathrm{RH}$. While with $150 \mathrm{MPa}-0 \mathrm{~s}$ they were $-0.46,1.25,3.80,3.94,6.74$, and $7.36 \%$, respectively. The results show that the TSE of HP-treated poplar generally increased after repeated humidity cycles, but the trend was clear only at high RH levels. Similar results were reported by Laine et al. (2013b), who stated that the phenomenon is caused by the set-recovery. 
Table 2. Thickness Swelling Efficiency of Poplar Subjected to Different HP Treatments Under Different RH Conditions

\begin{tabular}{|c|c|c|c|c|c|c|c|}
\hline \multicolumn{2}{|c|}{ Samples } & $\begin{array}{c}33.1 \% \\
\mathrm{RH}\end{array}$ & $54.4 \% \mathrm{RH}$ & $68.3 \% \mathrm{RH}$ & $75.5 \% \mathrm{RH}$ & $85.1 \% \mathrm{RH}$ & $94.6 \% \mathrm{RH}$ \\
\hline \multirow{2}{*}{ Control } & 1 & $\begin{array}{l}1.38 \pm \\
0.17^{d}\end{array}$ & $\begin{array}{c}2.02 \pm \\
0.47^{e}\end{array}$ & $\begin{array}{c}1.74 \pm \\
0.46^{c}\end{array}$ & $\begin{array}{r}2.33 \pm \\
0.52^{\mathrm{d}}\end{array}$ & $\begin{array}{c}3.40 \pm \\
1.01^{\mathrm{b}}\end{array}$ & $4.47 \pm 0.86^{e}$ \\
\hline & 2 & $\begin{array}{c}0.64 \pm \\
0.10^{d}\end{array}$ & $\begin{array}{l}1.29 \pm \\
0.37^{d}\end{array}$ & $\begin{array}{l}1.82 \pm \\
0.29^{b}\end{array}$ & $\begin{array}{c}2.54 \pm \\
0.42^{\mathrm{e}}\end{array}$ & $\begin{array}{c}3.09 \pm \\
0.70^{b}\end{array}$ & $4.09 \pm 0.65^{d}$ \\
\hline \multirow{2}{*}{$\begin{array}{c}50 \mathrm{MPa}- \\
0 \mathrm{~s}\end{array}$} & 1 & $\begin{array}{l}6.43 \pm \\
0.31^{\mathrm{abc}}\end{array}$ & $\begin{array}{l}14.70 \pm \\
0.42^{\text {abcd }}\end{array}$ & $\begin{array}{c}19.80 \pm \\
0.46^{\mathrm{ab}}\end{array}$ & $\begin{array}{c}26.7 \pm \\
0.70^{c}\end{array}$ & $\begin{array}{c}38.30 \pm \\
2.66^{\mathrm{a}}\end{array}$ & $57.4 \pm 4.46^{d}$ \\
\hline & 2 & $\begin{array}{c}5.97 \pm \\
0.42^{\mathrm{c}}\end{array}$ & $\begin{array}{l}15.77 \pm \\
0.78 \mathrm{abc}\end{array}$ & $\begin{array}{c}23.80 \pm \\
0.39 a\end{array}$ & $\begin{array}{c}31.00 \pm \\
1.13^{\mathrm{cd}}\end{array}$ & $\begin{array}{c}44.60 \pm \\
2.48^{\mathrm{a}}\end{array}$ & $\begin{array}{c}65.00 \pm \\
5.82^{c}\end{array}$ \\
\hline \multirow{2}{*}{$\begin{array}{c}50 \mathrm{MPa}- \\
30 \mathrm{~s}\end{array}$} & 1 & $\begin{array}{l}6.06 \pm \\
0.46 \mathrm{abc}\end{array}$ & $\begin{array}{l}15.78 \pm \\
0.96 \mathrm{abc}\end{array}$ & $\begin{array}{c}18.45 \pm \\
4.49 \mathrm{~b}\end{array}$ & $\begin{array}{c}26.77 \pm \\
4.12^{\mathrm{c}}\end{array}$ & $\begin{array}{c}37.60 \pm \\
1.53^{a}\end{array}$ & $\begin{array}{c}56.93 \pm \\
4.59 \mathrm{~d}\end{array}$ \\
\hline & 2 & $\begin{array}{l}5.59 \pm \\
0.24 \mathrm{bc}\end{array}$ & $\begin{array}{l}17.20 \pm \\
1.32^{\mathrm{abc}}\end{array}$ & $\begin{array}{c}22.75 \pm \\
5.49^{a}\end{array}$ & $\begin{array}{c}28.83 \pm \\
4.20^{\mathrm{d}}\end{array}$ & $\begin{array}{c}44.52 \pm \\
1.699^{a}\end{array}$ & $\begin{array}{c}64.73 \pm \\
4.81^{\mathrm{c}}\end{array}$ \\
\hline \multirow{2}{*}{$\begin{array}{c}50 \mathrm{MPa}- \\
60 \mathrm{~s}\end{array}$} & 1 & $\begin{array}{c}7.00 \pm \\
1.21^{\mathrm{c}}\end{array}$ & $\begin{array}{c}16.83 \pm \\
0.51^{\mathrm{a}}\end{array}$ & $\begin{array}{c}24.27 \pm \\
1.21^{\mathrm{a}}\end{array}$ & $\begin{array}{l}32.25 \pm \\
7.55^{\mathrm{abc}}\end{array}$ & $\begin{array}{c}41.98 \pm \\
1.27^{a}\end{array}$ & $\begin{array}{c}78.98 \pm \\
4.29 \mathrm{abc}\end{array}$ \\
\hline & 2 & $\begin{array}{l}6.16 \pm \\
1.43^{\mathrm{abc}}\end{array}$ & $\begin{array}{l}17.69 \pm \\
0.53^{\mathrm{abc}}\end{array}$ & $\begin{array}{c}28.73 \pm \\
1.55^{\mathrm{a}}\end{array}$ & $\begin{array}{l}34.57 \pm \\
7.33^{\mathrm{abcd}}\end{array}$ & $\begin{array}{c}47.75 \pm \\
2.58^{a}\end{array}$ & $\begin{array}{c}85.46 \pm \\
4.10^{\mathrm{ab}}\end{array}$ \\
\hline \multirow{2}{*}{$\begin{array}{c}50 \mathrm{MPa}- \\
300 \mathrm{~s}\end{array}$} & 1 & $\begin{array}{l}6.25 \pm \\
0.39 \mathrm{bc}\end{array}$ & $\begin{array}{l}14.04 \pm \\
1.41^{\mathrm{bcd}}\end{array}$ & $\begin{array}{c}21.56 \pm \\
4.82^{\mathrm{ab}}\end{array}$ & $\begin{array}{l}32.78 \pm \\
5.03^{\mathrm{abc}}\end{array}$ & $\begin{array}{c}43.52 \pm \\
4.27^{a}\end{array}$ & $\begin{array}{l}71.08 \pm \\
5.49^{\text {abcd }}\end{array}$ \\
\hline & 2 & $\begin{array}{l}6.72 \pm \\
0.25^{\mathrm{abc}}\end{array}$ & $\begin{array}{c}17.19 \pm \\
1.81^{\mathrm{abc}}\end{array}$ & $\begin{array}{c}25.99 \pm \\
4.81^{\mathrm{a}}\end{array}$ & $\begin{array}{l}36.78 \pm \\
5.67 \mathrm{abc}\end{array}$ & $\begin{array}{c}53.74 \pm \\
3.52^{\mathrm{a}}\end{array}$ & $\begin{array}{c}82.36 \pm \\
4.85^{\mathrm{ab}}\end{array}$ \\
\hline \multirow{2}{*}{$\begin{array}{c}100 \\
\mathrm{MPa}-0 \mathrm{~s}\end{array}$} & 1 & $\begin{array}{l}6.81 \pm \\
0.48^{\mathrm{abc}}\end{array}$ & $\begin{array}{l}14.12 \pm \\
0.11^{b c d}\end{array}$ & $\begin{array}{c}21.34 \pm \\
3.02^{\mathrm{ab}}\end{array}$ & $\begin{array}{c}29.56 \pm \\
3.13^{\mathrm{bc}}\end{array}$ & $\begin{array}{c}43.08 \pm \\
4.34^{\mathrm{a}}\end{array}$ & $\begin{array}{l}65.62 \pm \\
14.82^{c d}\end{array}$ \\
\hline & 2 & $\begin{array}{l}6.39 \pm \\
0.71^{\mathrm{abc}}\end{array}$ & $\begin{array}{c}15.37 \pm \\
0.34 \mathrm{bc}\end{array}$ & $\begin{array}{c}25.66 \pm \\
3.96^{\mathrm{a}}\end{array}$ & $\begin{array}{l}31.90 \pm \\
3.54 \text { bcd }\end{array}$ & $\begin{array}{c}49.65 \pm \\
5.08^{a}\end{array}$ & $\begin{array}{l}72.53 \pm \\
17.24^{\text {cd }}\end{array}$ \\
\hline \multirow{2}{*}{$\begin{array}{c}100 \\
\mathrm{MPa}-30 \mathrm{~s}\end{array}$} & 1 & $\begin{array}{c}7.73 \pm \\
0.52^{\mathrm{a}}\end{array}$ & $\begin{array}{c}16.28 \pm \\
1.93^{\mathrm{ab}}\end{array}$ & $\begin{array}{c}23.89 \pm \\
1.99^{a}\end{array}$ & $\begin{array}{r}33.07 \pm \\
1.9^{7 a b c}\end{array}$ & $\begin{array}{c}39.22 \pm \\
9.45^{\mathrm{a}}\end{array}$ & $\begin{array}{c}83.52 \pm \\
2.64^{\mathrm{a}}\end{array}$ \\
\hline & 2 & $\begin{array}{l}7.37 \pm \\
0.68^{\mathrm{ab}}\end{array}$ & $\begin{array}{l}16.92 \pm \\
2.11^{\mathrm{abc}}\end{array}$ & $\begin{array}{c}28.56 \pm \\
2.62^{\mathrm{a}}\end{array}$ & $\begin{array}{l}36.18 \pm \\
2.50^{\mathrm{abc}}\end{array}$ & $\begin{array}{c}44.53 \pm \\
10.97^{a}\end{array}$ & $\begin{array}{c}89.78 \pm \\
2.23^{\mathrm{ab}}\end{array}$ \\
\hline \multirow{2}{*}{$\begin{array}{c}100 \\
M P a-60 \mathrm{~s}\end{array}$} & 1 & $\begin{array}{c}6.09 \pm \\
0.57^{c}\end{array}$ & $\begin{array}{l}15.90 \pm \\
1.59 \mathrm{abc}\end{array}$ & $\begin{array}{c}23.37 \pm \\
0.56^{\mathrm{ab}}\end{array}$ & $\begin{array}{c}34.45 \pm \\
2.88^{\mathrm{ab}}\end{array}$ & $\begin{array}{c}38.53 \pm \\
6.53^{\mathrm{a}}\end{array}$ & $\begin{array}{l}68.48 \pm \\
13.10^{\text {bcd }}\end{array}$ \\
\hline & 2 & $\begin{array}{l}6.46 \pm \\
0.36^{\mathrm{abc}}\end{array}$ & $\begin{array}{l}16.65 \pm \\
1.30^{\mathrm{abc}} \\
\end{array}$ & $\begin{array}{c}27.20 \pm \\
0.87^{a}\end{array}$ & $\begin{array}{c}38.97 \pm \\
3.31^{\mathrm{ab}}\end{array}$ & $\begin{array}{c}45.54 \pm \\
7.76^{\mathrm{a}}\end{array}$ & $\begin{array}{l}75.21 \pm \\
13.28^{\mathrm{abc}}\end{array}$ \\
\hline \multirow{2}{*}{$\begin{array}{c}100 \\
\text { MPa-300 } \\
\text { s }\end{array}$} & 1 & $\begin{array}{l}6.16 \pm \\
0.30^{\mathrm{abc}}\end{array}$ & $\begin{array}{c}13.27 \pm \\
1.00^{\mathrm{d}}\end{array}$ & $\begin{array}{c}20.73 \pm \\
0.77^{\mathrm{ab}}\end{array}$ & $\begin{array}{c}33.00 \pm \\
0.79 \mathrm{abc}\end{array}$ & $\begin{array}{c}45.29 \pm \\
1.00^{a}\end{array}$ & $\begin{array}{c}65.47 \pm \\
4.46^{\mathrm{cd}}\end{array}$ \\
\hline & 2 & $\begin{array}{l}6.62 \pm \\
0.91^{\mathrm{abc}}\end{array}$ & $\begin{array}{c}16.44 \pm \\
1.54^{\mathrm{abc}}\end{array}$ & $\begin{array}{c}24.83 \pm \\
0.99 a\end{array}$ & $\begin{array}{c}37.72 \pm \\
1.08 \mathrm{abc}\end{array}$ & $\begin{array}{c}54.60 \pm \\
2.36^{\mathrm{a}}\end{array}$ & $\begin{array}{c}75.41 \pm \\
5.42^{\mathrm{abc}}\end{array}$ \\
\hline \multirow{2}{*}{$\begin{array}{c}150 \\
M P a-0 \mathrm{~s}\end{array}$} & 1 & $\begin{array}{l}7.07 \pm \\
0.36 \mathrm{abc}\end{array}$ & $\begin{array}{l}15.53 \pm \\
1.24 \text { abcd }\end{array}$ & $\begin{array}{c}22.08 \pm \\
3.58^{\mathrm{ab}}\end{array}$ & $\begin{array}{l}32.81 \pm \\
3.06 \mathrm{abc}\end{array}$ & $\begin{array}{c}44.83 \pm \\
4.29 a\end{array}$ & $\begin{array}{l}78.73 \pm \\
2.03^{\mathrm{abc}}\end{array}$ \\
\hline & 2 & $\begin{array}{l}6.61 \pm \\
0.60^{a b c}\end{array}$ & $\begin{array}{c}16.78 \pm \\
1.88 \mathrm{abc}\end{array}$ & $\begin{array}{c}25.89 \pm \\
4.23^{a}\end{array}$ & $\begin{array}{l}36.74 \pm \\
3.33^{a b c}\end{array}$ & $\begin{array}{c}51.57 \pm \\
4.16^{\mathrm{a}}\end{array}$ & $\begin{array}{c}86.08 \pm \\
2.11^{\mathrm{ab}}\end{array}$ \\
\hline \multirow{2}{*}{$\begin{array}{c}150 \\
\mathrm{MPa}-30 \mathrm{~s}\end{array}$} & 1 & $\begin{array}{l}6.53 \pm \\
1.66^{\mathrm{abc}}\end{array}$ & $\begin{array}{c}16.62 \pm \\
1.92^{\mathrm{a}}\end{array}$ & $\begin{array}{c}19.88 \pm \\
2.13^{\mathrm{ab}}\end{array}$ & $\begin{array}{l}32.15 \pm \\
0.83^{\mathrm{abc}}\end{array}$ & $\begin{array}{c}45.41 \pm \\
11.62^{\mathrm{a}}\end{array}$ & $\begin{array}{c}81.42 \pm \\
7.37 \mathrm{ab}\end{array}$ \\
\hline & 2 & $\begin{array}{l}6.98 \pm \\
1.47 \mathrm{abc}\end{array}$ & $\begin{array}{c}18.24 \pm \\
2.48^{\mathrm{ab}}\end{array}$ & $\begin{array}{c}22.96 \pm \\
2.91^{\mathrm{a}}\end{array}$ & $\begin{array}{l}34.51 \pm \\
0.84^{\text {abcd }}\end{array}$ & $\begin{array}{c}53.19 \pm \\
13.09^{a}\end{array}$ & $\begin{array}{c}89.14 \pm \\
8.72^{\mathrm{ab}}\end{array}$ \\
\hline \multirow{3}{*}{$\begin{array}{c}150 \\
M P a-60 \mathrm{~s}\end{array}$} & 1 & $\begin{array}{l}7.54 \pm \\
0.22^{\mathrm{ab}}\end{array}$ & $\begin{array}{c}16.28 \pm \\
0.68^{\mathrm{ab}}\end{array}$ & $\begin{array}{c}19.88 \pm \\
2.82^{\mathrm{ab}}\end{array}$ & $\begin{array}{c}36.83 \pm \\
2.09^{a}\end{array}$ & $\begin{array}{c}45.26 \pm \\
1.53^{\mathrm{a}}\end{array}$ & $\begin{array}{l}76.08 \pm \\
7.36^{\mathrm{abc}}\end{array}$ \\
\hline & 2 & $\begin{array}{l}7.02 \pm \\
0.44^{\mathrm{ab}}\end{array}$ & $\begin{array}{l}17.76 \pm \\
0.43^{\mathrm{abc}}\end{array}$ & $\begin{array}{c}24.31 \pm \\
3.03^{\mathrm{a}}\end{array}$ & $\begin{array}{c}40.24 \pm \\
2.24^{\mathrm{a}}\end{array}$ & $\begin{array}{c}51.70 \pm \\
1.43^{\mathrm{a}}\end{array}$ & $\begin{array}{c}83.98 \pm \\
8.10^{\mathrm{ab}}\end{array}$ \\
\hline & 1 & $\begin{array}{l}6.53 \pm \\
0.73^{\mathrm{abc}}\end{array}$ & $\begin{array}{l}14.95 \pm \\
1.60^{\text {abcd }}\end{array}$ & $\begin{array}{c}21.55 \pm \\
2.88^{\mathrm{ab}}\end{array}$ & $\begin{array}{c}34.49 \pm \\
3.24^{\mathrm{ab}}\end{array}$ & $\begin{array}{c}44.89 \pm \\
2.64^{\mathrm{a}}\end{array}$ & $\begin{array}{c}68.75 \pm \\
11.21^{\mathrm{abcd}}\end{array}$ \\
\hline
\end{tabular}




\begin{tabular}{|c|c|c|c|c|c|c|c|}
\hline $\begin{array}{c}150 \\
\mathrm{MPa}-300 \\
\mathrm{~s}\end{array}$ & 2 & $\begin{array}{c}7.52 \pm \\
0.83^{a}\end{array}$ & $\begin{array}{c}18.84 \pm \\
1.90^{\mathrm{a}}\end{array}$ & $\begin{array}{c}26.88 \pm \\
3.72^{\mathrm{a}}\end{array}$ & $\begin{array}{c}38.87 \pm \\
3.80^{\mathrm{ab}}\end{array}$ & $\begin{array}{c}51.98 \pm \\
3.31^{\mathrm{a}}\end{array}$ & $\begin{array}{l}81.47 \pm \\
11.81^{\mathrm{ab}}\end{array}$ \\
\hline \multirow{2}{*}{$\begin{array}{c}200 \\
\mathrm{MPa}-0 \mathrm{~s}\end{array}$} & 1 & $\begin{array}{l}7.06 \pm \\
0.53^{\mathrm{abc}}\end{array}$ & $\begin{array}{c}15.98 \pm \\
2.67 \mathrm{ab}\end{array}$ & $\begin{array}{c}23.03 \pm \\
1.33^{\mathrm{ab}}\end{array}$ & $\begin{array}{c}35.81 \pm \\
3.09 \mathrm{ab}\end{array}$ & $\begin{array}{c}45.34 \pm \\
4.82^{\mathrm{a}}\end{array}$ & $\begin{array}{l}71.37 \pm \\
8.62^{\mathrm{abcd}}\end{array}$ \\
\hline & 2 & $\begin{array}{l}6.30 \pm \\
0.39 \mathrm{abc}\end{array}$ & $\begin{array}{l}17.32 \pm \\
3.26^{\mathrm{abc}}\end{array}$ & $\begin{array}{c}27.47 \pm \\
1.62^{\mathrm{a}} \\
\end{array}$ & $\begin{array}{c}39.60 \pm \\
2.01^{\mathrm{a}}\end{array}$ & $\begin{array}{c}51.50 \pm \\
5.13^{\mathrm{a}}\end{array}$ & $\begin{array}{l}78.35 \pm \\
10.37^{\mathrm{abc}}\end{array}$ \\
\hline \multirow{2}{*}{$\begin{array}{c}200 \\
M P a-30 s\end{array}$} & 1 & $\begin{array}{l}6.68 \pm \\
0.53^{\mathrm{abc}}\end{array}$ & $\begin{array}{l}14.71 \pm \\
0.55^{\mathrm{abcd}}\end{array}$ & $\begin{array}{c}19.76 \pm \\
1.18^{a b}\end{array}$ & $\begin{array}{l}32.18 \pm \\
2.54^{\mathrm{abc}}\end{array}$ & $\begin{array}{c}43.75 \pm \\
6.44^{\mathrm{a}}\end{array}$ & $\begin{array}{l}75.41 \pm \\
8.67 \mathrm{abc}\end{array}$ \\
\hline & 2 & $\begin{array}{l}6.06 \pm \\
0.48^{\mathrm{abc}}\end{array}$ & $\begin{array}{l}16.20 \pm \\
0.99 \mathrm{abc}\end{array}$ & $\begin{array}{c}23.16 \pm \\
1.11^{\mathrm{a}}\end{array}$ & $\begin{array}{l}37.13 \pm \\
3.65^{\mathrm{abc}}\end{array}$ & $\begin{array}{c}49.42 \pm \\
7.50^{\mathrm{a}}\end{array}$ & $\begin{array}{l}83.01 \pm \\
10.04^{\mathrm{ab}}\end{array}$ \\
\hline \multirow{2}{*}{$\begin{array}{c}200 \\
\mathrm{MPa}-60 \mathrm{~s}\end{array}$} & 1 & $\begin{array}{l}6.55 \pm \\
0.81 \mathrm{abc}\end{array}$ & $\begin{array}{l}13.99 \pm \\
0.80^{\text {bcd }}\end{array}$ & $\begin{array}{c}20.24 \pm \\
5.03^{\mathrm{ab}}\end{array}$ & $\begin{array}{l}32.08 \pm \\
6.07 \mathrm{abc}\end{array}$ & $\begin{array}{c}39.69 \pm \\
7.17^{\mathrm{a}}\end{array}$ & $\begin{array}{l}71.23 \pm \\
4.95^{\mathrm{abcd}}\end{array}$ \\
\hline & 2 & $\begin{array}{l}6.22 \pm \\
0.33^{\mathrm{abc}}\end{array}$ & $\begin{array}{c}14.85 \pm \\
0.81^{c}\end{array}$ & $\begin{array}{c}23.94 \pm \\
5.75^{\mathrm{a}}\end{array}$ & $\begin{array}{l}35.12 \pm \\
6.22^{\mathrm{abcd}}\end{array}$ & $\begin{array}{c}45.13 \pm \\
8.41^{\mathrm{a}}\end{array}$ & $\begin{array}{l}79.35 \pm \\
5.88^{\mathrm{abc}}\end{array}$ \\
\hline \multirow{2}{*}{$\begin{array}{c}200 \\
\mathrm{MPa}-300 \\
\mathrm{~s}\end{array}$} & 1 & $\begin{array}{l}6.07 \pm \\
0.63^{c}\end{array}$ & $\begin{array}{c}13.43 \pm \\
0.82^{\text {cd }}\end{array}$ & $\begin{array}{c}21.56 \pm \\
1.55^{\mathrm{ab}}\end{array}$ & $\begin{array}{c}34.65 \pm \\
2.50^{\mathrm{ab}}\end{array}$ & $\begin{array}{c}42.35 \pm \\
2.89^{\mathrm{a}}\end{array}$ & $\begin{array}{l}70.91 \pm \\
7.46^{\text {abcd }}\end{array}$ \\
\hline & 2 & $\begin{array}{l}6.71 \pm \\
0.85^{a b c}\end{array}$ & $\begin{array}{l}16.44 \pm \\
1.20^{\mathrm{abc}}\end{array}$ & $\begin{array}{c}25.90 \pm \\
1.97^{\mathrm{a}}\end{array}$ & $\begin{array}{c}39.63 \pm \\
3.08^{a}\end{array}$ & $\begin{array}{c}51.12 \pm \\
4.44^{\mathrm{a}}\end{array}$ & $\begin{array}{c}83.53 \pm \\
8.82^{\mathrm{ab}}\end{array}$ \\
\hline
\end{tabular}

The compressed wood begins to recover when the environmental RH exceeds a certain value, and then the resulting irreversible deformation leads to an increase in TSE after next dry-humidify cycle. Therefore, a clear increase in the set-recovery value can be considered as the RH threshold after which set-recovery starts to manifest itself (Laine $e t$ al. 2013). According to the TSE results, the RH threshold for HP-densified samples appears to be between 33 and 54\%. Again, conducting these experiments in a traditional way will only lead to the high humidity results and the useful information at the lower RH will be lost.

\section{Effect of High Pressure Densification Treatment on Irreversible Swelling}

The irreversible swelling (IS) is an important indicator to measure dimensional stability of wood, and to analyze the permanent deformation during the humidificationdehumidification cycle. Table 2 shows the irreversible swelling of poplar following various HP treatments. As expected, the IS of HP-treated poplar was similar to the TSE discussed above, which increased with enhancing RH. Irreversible swelling of all HP-densified wood samples varied irregularly within the range of 4.75 to $16.4 \%$ at $33 \% \mathrm{RH}$, while no clear trends were found between the first and second humid-dry cycle. The results indicated that the IS of compressed wood at 33\% RH may have been due to possible measurement uncertainty errors. However, the IS of treated samples were clearly observed (15 to 85\%) at $\geq 54 \% \mathrm{RH}$. Therefore, the RH threshold for HP-compressed poplar was between 33 and $54 \%$, which was different from other previous studies that reported the RH threshold of hot-pressed densified wood was between 65 and 75\% RH (Laine et al. 2013). It should be noted that high temperatures can damage the hydroxyl groups of wood polymers, which can cause its hygroscopic properties to decrease and result in an increase in the $\mathrm{RH}$ threshold of compressed wood. In the hot-pressing treatment, the samples needed to be treated at a high temperature for several hours, while wood is compressed by HP technology at room temperature, which is consistent with the conclusion of Laine et al. (2013). In addition, the extent of IS increased rapidly when the RH exceeded the threshold value. The IS value for $50 \mathrm{MPa}-30 \mathrm{~s}$ was $22.5 \%, 27.4 \%, 33.3 \%, 40.9 \%$, and $61.0 \%$, after the first dry-humid cycle test at 54\%, 68\%, 76\%, 85\%, and 95\% RH, respectively. Finally, 
the set-recovery of HP-densified poplar increased quickly at extremely high levels (38 to $85 \%$ ) when RH was between $85 \%$ and $95 \%$, which is highly undesirable.

Comparing the samples treated at the same pressure, it was found that the pressure holding time also affected the IS of compressed wood at the same RH between 54 and $95 \%$ (Table 3). The IS value of poplar samples with $300 \mathrm{~s}$ holding time was much more than those of the other treatment group, while no obvious difference in the IS values were with shorter holding times between 0 and $60 \mathrm{~s}$. The increased holding time during HP treatment resulted in a decrease in the RH threshold. Additionally, the IS value of all treated specimens significantly increased when the environmental RH increased to $85 \%$ to $95 \%$, regardless of holding time. This could mean that the $\mathrm{RH}$ threshold for controlling the extent of set-recovery was not affected by the holding time.

Furthermore, the IS value of all densified wood samples were increased after repeated dry-humid cycles at 54 to $95 \%$ RH. However, a previous study (Yu et al. 2017) showed that the densified poplar samples usually increased slightly after HP treatment in air-dry condition, and then the thickness became stable at the end of the TS test. The difference between two phenomena may have been related to the change of hydrogen bonding during the dry-humid cycle test. The water molecules that were adsorbed by wood directly combined with the hydroxyl groups of wood's cellulose and hemicellulose to form hydrogen bonds, thus generating swelling stress in the interior of wood. When the effect of swelling stress reached a certain level, the metastable state of compressed wood was destroyed, resulting in permanent deformation (Blomberg and Persson 2007). Therefore, the set-recovery appeared to be significantly higher after the second dry-humid cycle test that yielded one more moisture absorption and expansion process. In addition, the effect of wood's mechano-sorptive creep can also explain the phenomenon above. The natural swelling deformation of wood increases abnormally under load when its moisture content is increased with environmental RH (Navi et al. 2002; Saifouni et al. 2016). Laine et al. (2013) reported that a swelling stress formed in the interior of the cell wall when the compressed wood absorbed moisture, which is similar with wood subjected to an external load, resulting in a simple effect of mechano-sorptive creep. Additionally, Zhang (2010b) studied the mechano-sorptive creep of wood under different load conditions. The creep of wood formed when wood that was subjected to external load absorbed moisture from the outside, but the creep could not fully recover under no load during the desorption process. It is expected that partial creep deformation will remain. Thus, the IS value continued to enhance after each dry-humidity cycle test. 
Table 3. Irreversible Swelling of Poplar Treated by Different High Pressure Treatments Under Different RH Conditions

\begin{tabular}{|c|c|c|c|c|c|c|c|}
\hline \multicolumn{2}{|c|}{ Samples } & $33.1 \% \mathrm{RH}$ & $54.4 \% \mathrm{RH}$ & $68.3 \% \mathrm{RH}$ & $75.5 \% \mathrm{RH}$ & $85.1 \% \mathrm{RH}$ & $94.6 \% \mathrm{RH}$ \\
\hline \multirow{2}{*}{$\begin{array}{c}50 \mathrm{MPa}-0 \\
\mathrm{~s}\end{array}$} & 1 & $\begin{array}{c}11.60 \pm \\
5.15\end{array}$ & $\begin{array}{c}24.90 \pm \\
1.78\end{array}$ & $\begin{array}{c}27.90 \pm \\
2.21\end{array}$ & $\begin{array}{c}30.00 \pm \\
1.11\end{array}$ & $\begin{array}{c}40.10 \pm \\
0.24\end{array}$ & $\begin{array}{c}57.30 \pm \\
2.65\end{array}$ \\
\hline & 2 & $\begin{array}{c}12.39 \pm \\
6.90\end{array}$ & $\begin{array}{c}33.59 \pm \\
0.84\end{array}$ & $\begin{array}{c}37.63 \pm \\
1.38\end{array}$ & $\begin{array}{c}43.03 \pm \\
0.97\end{array}$ & $\begin{array}{c}50.19 \pm \\
1.15\end{array}$ & $\begin{array}{c}66.44 \pm \\
2.41\end{array}$ \\
\hline \multirow{2}{*}{$\begin{array}{c}50 \mathrm{MPa}- \\
30 \mathrm{~s}\end{array}$} & 1 & $\begin{array}{c}11.29 \pm \\
7.18\end{array}$ & $\begin{array}{c}24.09 \pm \\
1.08\end{array}$ & $\begin{array}{c}30.79 \pm \\
0.60\end{array}$ & $\begin{array}{c}32.02 \pm \\
3.17\end{array}$ & $\begin{array}{c}39.97 \pm \\
1.55\end{array}$ & $\begin{array}{c}60.81 \pm \\
4.02\end{array}$ \\
\hline & 2 & $\begin{array}{c}11.03 \pm \\
1.50\end{array}$ & $\begin{array}{c}32.70 \pm \\
0.62\end{array}$ & $\begin{array}{c}39.49 \pm \\
1.03\end{array}$ & $\begin{array}{c}44.81 \pm \\
1.05\end{array}$ & $\begin{array}{c}51.27 \pm \\
2.65\end{array}$ & $\begin{array}{c}67.60 \pm \\
1.58\end{array}$ \\
\hline \multirow{2}{*}{$\begin{array}{c}50 \mathrm{MPa}- \\
60 \mathrm{~s}\end{array}$} & 1 & $\begin{array}{c}5.22 \pm \\
5.70\end{array}$ & $\begin{array}{c}22.53 \pm \\
8.51\end{array}$ & $\begin{array}{c}27.36 \pm \\
3.15\end{array}$ & $\begin{array}{c}33.27 \pm \\
1.26\end{array}$ & $\begin{array}{c}40.90 \pm \\
2.23\end{array}$ & $\begin{array}{c}61.04 \pm \\
1.33\end{array}$ \\
\hline & 2 & $\begin{array}{c}5.74 \pm \\
2.45\end{array}$ & $\begin{array}{c}31.68 \pm \\
3.37\end{array}$ & $\begin{array}{c}36.35 \pm \\
3.44\end{array}$ & $\begin{array}{c}44.92 \pm \\
2.37\end{array}$ & $\begin{array}{c}50.26 \pm \\
2.89\end{array}$ & $\begin{array}{c}64.04 \pm \\
3.21\end{array}$ \\
\hline \multirow{2}{*}{$\begin{array}{c}50 \mathrm{MPa}- \\
300 \mathrm{~s}\end{array}$} & 1 & $\begin{array}{c}13.66 \pm \\
2.54\end{array}$ & $\begin{array}{c}26.40 \pm \\
2.11\end{array}$ & $\begin{array}{c}33.87 \pm \\
0.85\end{array}$ & $\begin{array}{c}43.79 \pm \\
0.51\end{array}$ & $\begin{array}{c}56.30 \pm \\
3.44\end{array}$ & $\begin{array}{c}67.98 \pm \\
4.27\end{array}$ \\
\hline & 2 & $\begin{array}{c}21.46 \pm \\
1.93\end{array}$ & $\begin{array}{c}37.08 \pm \\
0.22\end{array}$ & $\begin{array}{c}43.57 \pm \\
1.89\end{array}$ & $\begin{array}{c}53.78 \pm \\
1.15\end{array}$ & $\begin{array}{c}56.62 \pm \\
1.04\end{array}$ & $\begin{array}{c}66.37 \pm \\
2.07\end{array}$ \\
\hline \multirow{2}{*}{$\begin{array}{c}100 \mathrm{MPa}- \\
0 \mathrm{~s}\end{array}$} & 1 & $\begin{array}{c}8.43 \pm \\
2.80\end{array}$ & $\begin{array}{c}19.75 \pm \\
3.44\end{array}$ & $\begin{array}{c}28.47 \pm \\
3.74\end{array}$ & $\begin{array}{c}29.51 \pm \\
4.68\end{array}$ & $\begin{array}{c}40.92 \pm \\
1.48\end{array}$ & $\begin{array}{c}55.36 \pm \\
2.84\end{array}$ \\
\hline & 2 & $\begin{array}{c}10.07 \pm \\
2.89\end{array}$ & $\begin{array}{c}31.48 \pm \\
2.91\end{array}$ & $\begin{array}{c}39.11 \pm \\
2.89\end{array}$ & $\begin{array}{c}41.99 \pm \\
3.26\end{array}$ & $\begin{array}{c}51.41 \pm \\
1.51\end{array}$ & $\begin{array}{c}61.30 \pm \\
0.82\end{array}$ \\
\hline \multirow{2}{*}{$\begin{array}{c}100 \mathrm{MPa}- \\
30 \mathrm{~s}\end{array}$} & 1 & $\begin{array}{c}8.98 \pm \\
1.82\end{array}$ & $\begin{array}{c}20.87 \pm \\
2.41\end{array}$ & $\begin{array}{c}30.09 \pm \\
3.73\end{array}$ & $\begin{array}{c}31.69 \pm \\
5.39\end{array}$ & $\begin{array}{c}37.62 \pm \\
1.97\end{array}$ & $\begin{array}{c}57.53 \pm \\
2.51\end{array}$ \\
\hline & 2 & $\begin{array}{c}15.71 \pm \\
2.45\end{array}$ & $\begin{array}{c}30.44 \pm \\
1.99\end{array}$ & $\begin{array}{c}38.35 \pm \\
2.79\end{array}$ & $\begin{array}{c}42.72 \pm \\
4.38\end{array}$ & $\begin{array}{c}48.09 \pm \\
1.79\end{array}$ & $\begin{array}{c}63.36 \pm \\
1.93\end{array}$ \\
\hline \multirow{2}{*}{$\begin{array}{c}100 \mathrm{MPa}- \\
60 \mathrm{~s}\end{array}$} & 1 & $\begin{array}{c}10.96 \pm \\
3.91\end{array}$ & $\begin{array}{c}22.74 \pm \\
2.79\end{array}$ & $\begin{array}{c}25.53 \pm \\
2.46\end{array}$ & $\begin{array}{c}39.88 \pm \\
3.18\end{array}$ & $\begin{array}{c}41.58 \pm \\
3.23\end{array}$ & $\begin{array}{c}56.34 \pm \\
2.10\end{array}$ \\
\hline & 2 & $\begin{array}{c}22.28 \pm \\
7.63\end{array}$ & $\begin{array}{c}32.20 \pm \\
3.38\end{array}$ & $\begin{array}{c}37.33 \pm \\
1.95\end{array}$ & $\begin{array}{c}49.11 \pm \\
2.77\end{array}$ & $\begin{array}{c}53.40 \pm \\
2.83\end{array}$ & $\begin{array}{c}62.13 \pm \\
3.06\end{array}$ \\
\hline \multirow{2}{*}{$\begin{array}{c}100 \mathrm{MPa}- \\
300 \mathrm{~s}\end{array}$} & 1 & $\begin{array}{c}8.28 \pm \\
2.32 \\
\end{array}$ & $\begin{array}{c}24.70 \pm \\
6.02\end{array}$ & $\begin{array}{c}32.04 \pm \\
1.76\end{array}$ & $\begin{array}{c}42.55 \pm \\
1.76\end{array}$ & $\begin{array}{c}48.67 \pm \\
3.60\end{array}$ & $\begin{array}{c}55.70 \pm \\
1.45\end{array}$ \\
\hline & 2 & $\begin{array}{c}15.70 \pm \\
1.68\end{array}$ & $\begin{array}{c}33.99 \pm \\
4.98\end{array}$ & $\begin{array}{c}41.03 \pm \\
2.61\end{array}$ & $\begin{array}{c}52.17 \pm \\
0.83\end{array}$ & $\begin{array}{c}51.80 \pm \\
2.01\end{array}$ & $\begin{array}{c}62.53 \pm \\
4.85\end{array}$ \\
\hline \multirow{2}{*}{$\begin{array}{c}150 \mathrm{MPa}- \\
0 \mathrm{~s}\end{array}$} & 1 & $\begin{array}{c}4.75 \pm \\
4.33\end{array}$ & $\begin{array}{c}21.30 \pm \\
1.55\end{array}$ & $\begin{array}{c}23.70 \pm \\
6.06\end{array}$ & $\begin{array}{c}35.60 \pm \\
4.87\end{array}$ & $\begin{array}{c}38.86 \pm \\
1.39\end{array}$ & $\begin{array}{c}56.80 \pm \\
2.96\end{array}$ \\
\hline & 2 & $\begin{array}{c}5.99 \pm \\
4.82\end{array}$ & $\begin{array}{c}29.26 \pm \\
2.51\end{array}$ & $\begin{array}{c}35.73 \pm \\
3.51\end{array}$ & $\begin{array}{c}44.13 \pm \\
5.34\end{array}$ & $\begin{array}{c}49.02 \pm \\
1.28\end{array}$ & $\begin{array}{c}63.69 \pm \\
3.21\end{array}$ \\
\hline \multirow{2}{*}{$\begin{array}{c}150 \mathrm{MPa}- \\
30 \mathrm{~s}\end{array}$} & 1 & $\begin{array}{c}12.54 \pm \\
1.20\end{array}$ & $\begin{array}{c}16.86 \pm \\
0.95\end{array}$ & $\begin{array}{c}19.61 \pm \\
5.56\end{array}$ & $\begin{array}{c}30.58 \pm \\
1.48\end{array}$ & $\begin{array}{c}42.09 \pm \\
3.76\end{array}$ & $\begin{array}{c}56.05 \pm \\
0.62\end{array}$ \\
\hline & 2 & $\begin{array}{c}24.09 \pm \\
2.16\end{array}$ & $\begin{array}{c}28.00 \pm \\
1.00\end{array}$ & $\begin{array}{c}29.45 \pm \\
7.89\end{array}$ & $\begin{array}{c}41.14 \pm \\
0.71\end{array}$ & $\begin{array}{c}54.89 \pm \\
4.97\end{array}$ & $\begin{array}{c}62.20 \pm \\
1.68\end{array}$ \\
\hline \multirow{2}{*}{$\begin{array}{c}150 \mathrm{MPa}- \\
60 \mathrm{~s}\end{array}$} & 1 & $\begin{array}{c}5.78 \pm \\
1.56\end{array}$ & $\begin{array}{c}23.46 \pm \\
1.46\end{array}$ & $\begin{array}{c}25.04 \pm \\
4.24\end{array}$ & $\begin{array}{c}34.74 \pm \\
0.30\end{array}$ & $\begin{array}{c}37.04 \pm \\
0.99\end{array}$ & $\begin{array}{c}55.30 \pm \\
2.33\end{array}$ \\
\hline & 2 & $\begin{array}{c}9.92 \pm \\
3.73\end{array}$ & $\begin{array}{c}31.96 \pm \\
1.41\end{array}$ & $\begin{array}{c}35.53 \pm \\
3.67\end{array}$ & $\begin{array}{c}46.37 \pm \\
1.27\end{array}$ & $\begin{array}{c}48.16 \pm \\
1.05\end{array}$ & $\begin{array}{c}61.28 \pm \\
2.05\end{array}$ \\
\hline \multirow{2}{*}{$\begin{array}{c}150 \mathrm{MPa}- \\
300 \mathrm{~s}\end{array}$} & 1 & $\begin{array}{c}16.44 \pm \\
0.32\end{array}$ & $\begin{array}{c}29.41 \pm \\
0.62\end{array}$ & $\begin{array}{c}40.06 \pm \\
5.49\end{array}$ & $\begin{array}{c}43.73 \pm \\
2.56\end{array}$ & $\begin{array}{c}45.54 \pm \\
3.09\end{array}$ & $\begin{array}{c}63.38 \pm \\
3.36\end{array}$ \\
\hline & 2 & $\begin{array}{c}34.23 \pm \\
2.38\end{array}$ & $\begin{array}{c}36.66 \pm \\
1.93\end{array}$ & $\begin{array}{c}44.01 \pm \\
1.71\end{array}$ & $\begin{array}{c}53.53 \pm \\
1.76\end{array}$ & $\begin{array}{c}60.24 \pm \\
3.12\end{array}$ & $\begin{array}{c}61.57 \pm \\
1.21\end{array}$ \\
\hline $\begin{array}{c}200 \mathrm{MPa}- \\
0 \mathrm{~s}\end{array}$ & 1 & $\begin{array}{c}4.64 \pm \\
1.66\end{array}$ & $\begin{array}{c}21.88 \pm \\
3.01\end{array}$ & $\begin{array}{c}27.71 \pm \\
2.96\end{array}$ & $\begin{array}{c}38.33 \pm \\
1.72\end{array}$ & $\begin{array}{c}36.76 \pm \\
1.94\end{array}$ & $\begin{array}{c}52.97 \pm \\
3.67\end{array}$ \\
\hline
\end{tabular}




\begin{tabular}{|c|c|c|c|c|c|c|c|}
\hline & 2 & $5.32 \pm$ & $30.01 \pm$ & $37.40 \pm$ & $46.53 \pm$ & $42.18 \pm$ & $60.53 \pm$ \\
& & 1.52 & 3.56 & 1.92 & 1.69 & 9.27 & 3.40 \\
\hline \multirow{3}{*}{$200 \mathrm{MPa}-$} & 1 & $9.62 \pm$ & $18.22 \pm$ & $22.99 \pm$ & $42.01 \pm$ & $35.67 \pm$ & $58.19 \pm$ \\
$30 \mathrm{~s}$ & & 2.62 & 1.98 & 3.95 & 3.17 & 1.23 & 1.64 \\
\cline { 2 - 8 } & 2 & $12.77 \pm$ & $26.28 \pm$ & $32.22 \pm$ & $45.72 \pm$ & $47.67 \pm$ & $64.31 \pm$ \\
& & 3.42 & 1.36 & 4.93 & 1.92 & 2.52 & 0.99 \\
\hline \multirow{3}{*}{$200 \mathrm{MPa}-$} & 1 & $9.42 \pm$ & $25.81 \pm$ & $23.12 \pm$ & $33.60 \pm$ & $33.92 \pm$ & $56.84 \pm$ \\
$60 \mathrm{~s}$ & 2 & 4.43 & 1.39 & 1.65 & 2.01 & 5.40 & 1.57 \\
\cline { 2 - 8 } & 2 & $3.34 \pm$ & $30.70 \pm$ & $32.98 \pm$ & $43.77 \pm$ & $46.10 \pm$ & $60.95 \pm$ \\
& & 3.93 & 3.10 & 3.20 & 2.55 & 4.72 & 2.11 \\
\hline \multirow{3}{*}{$200 \mathrm{MPa}-$} & 1 & $9.80 \pm$ & $24.35 \pm$ & $35.27 \pm$ & $44.19 \pm$ & $50.85 \pm$ & $64.94 \pm$ \\
$300 \mathrm{~s}$ & 2 & 2.08 & 1.76 & 2.39 & 1.30 & 5.57 & 1.76 \\
\cline { 2 - 8 } & 2 & $13.43 \pm$ & $34.33 \pm$ & $42.16 \pm$ & $52.73 \pm$ & $53.43 \pm$ & $62.81 \pm$ \\
& & 3.07 & 0.80 & 2.12 & 0.32 & 1.84 & 1.44 \\
\hline
\end{tabular}

\section{CONCLUSIONS}

Compression recovery (CR) and delayed elastic strain (DES) of high pressure (HP) densified wood were studied. The subsequent equilibrium moisture content and swelling properties were evaluated at different relative humidity $(\mathrm{RH})$ conditions.

1. The HP treatment substantially decreased the volume of poplar samples at selected conditions, and the compression ratio for all sample types was higher than $50 \%$. The CR increased rapidly with pressure up to $50 \mathrm{MPa}$ and then stabilized with increasing pressure. The $100 \mathrm{MPa}$ treatment provided an important turning point tendency. In addition, prolonged holding time (300 s) also improved the effect of densification of poplar.

2. The results of DES indicated that there was partial reverting of the deformation of compressed poplar wood after HP treatment at all researched conditions, while there were no significant differences in the final DES. The EMC results demonstrated that moisture content isotherms of wood were not influenced by HP treatment. The TSE of poplar was enhanced after HP treatment at all RH conditions. The HP-treated poplar was stable at RH between 33 and 54\%, while the extent of set-recovery appeared to increase rapidly at RH values higher than $85 \%$. In addition, the RH threshold of samples decreased significantly with a holding time of $30 \mathrm{~s}$, which may have been required for creating stronger bonding to resist $\mathrm{RH}$ dependent swelling.

3. The results under the employed methodology also indicated the set-recovery was minimal in the lower range of the RH employed for storage indicating such HP-treated wood would perform well under normal indoor RH conditions employed at comfort levels. The traditional methods indicated the contrary because they only subject the wood to high humidity conditions.

\section{ACKNOWLEDGEMENTS}

This study is funded by Yulin Wood Industry Co., Ltd., Henan Province, China. The authors are grateful for the support of Yulin Wood Industry Co., Ltd., and the College of Biosystems Engineering and Food Science of Zhejiang University, Hangzhou, China. 


\section{REFERENCES CITED}

Ahmed, S. A., Morén, T., Hagman, O., Cloutier, A., Fang, C.-H., and Elustondo, D. (2013). "Anatomical properties and process parameters affecting blister/blow formation in densified European aspen and downy birch sapwood boards by thermohygro-mechanical compression," Journal of Materials Science 48(24), 8571-8579. DOI: $10.1007 / \mathrm{s} 10853-013-7679-9$

Bahadori, H., Hasheminezhad, A., and Alizadeh, S. (2019). "The influence of natural pozzolans structure on marl soil stabilization," Transportation Infrastructure Geotechnology 1-9. DOI: 10.1007/s40515-019-00089-4

Bahadori, H., Hasheminezhad, A., and Mohamadi asl, S. (2019). "Stabilisation of Urmia Lake peat using natural and artificial pozzolans," Proceedings of the Institution of Civil Engineers-Ground Improvement, 1-10. DOI: 10.1680/jgrim.19.00024

Bahadori, H., Hasheminezhad, A., and Taghizadeh, F. (2018). "Experimental study on marl soil stabilization using natural pozzolans," Journal of Materials in Civil Engineering 31(2), 04018363. DOI: 10.1061/(ASCE)MT.1943-5533.0002577.

Blomberg J. (2005). "Elastic strain at semi-isostatic compression of Scots pine (Pinus sylvestris)," Journal of Wood Science 51(4), 401-404. DOI: 10.1007/s10086-0040666-7

Blomberg, J., and Persson, B. (2004). "Plastic deformation in small clear pieces of Scots pine (Pinus sylvestris) during densification with the CaLignum process," Journal of Wood Science 50(4), 307-314. DOI: 10.1007/s10086-003-0566-2

Blomberg, J., and Persson, B. (2007). "Swelling pressure of semi-isostatically densified wood under different mechanical restraints," Wood Science and Technology 41(5), 401-415. DOI: 10.1007/s00226-006-0118-1

Blomberg, J., Persson, B., and Bexell, U. (2006). "Effects of semi-isostatic densification on anatomy and cell-shape recovery on soaking," Holzforschung 13(3), 151-331. DOI: 10.1515/HF.2006.052

Ding, T., Gu, L. B., and Cai, J. B. (2015). "Effects of heat treatment on the moisture absorption characteristic and dimensional stability of wood" Journal of Nanjing Forestry University (2), 143-147.

Fang, C. H., Mariotti, N., Cloutier, A., Koubaa, A., and Blanchet, P. (2012). "Densification of wood veneers by compression combined with heat and steam," European Journal of Wood and Wood Products 70(1-3), 155-163. DOI: 10.1007/s00107-011-0524-4

Gao, Z., Huang, R., Lu, J., Chen, Z., Guo, F., and Zhan, T. (2016). "Sandwich compression of wood: control of creating density gradient on lumber thickness and properties of compressed wood," Wood Science and Technology 50(4), 833-844. DOI: $10.1007 / \mathrm{s} 00226-016-0824-2$

Jiang, X., Li, H., Ramaswamy, H. S., Zhu, S., and Yu, Y. (2018). "Moisture sorption isotherms and isosteric heats of sorption of high pressure treated paulownia," Transactions of the ASABE 62(1), 105-114. DOI: 10.13031/trans.12899

Kutnar, A., and Kamke, F. A. (2012). "Influence of temperature and steam environment on set recovery of compressive deformation of wood," Wood Science and Technology 46(5), 953-964. DOI: 10.1007/s00226-011-0456-5

Kutnar, A., Kamke, F. A., and Sernek, M. (2009). "Density profile and morphology of viscoelastic thermal compressed wood," Wood Science and Technology 43(1-2), 5768. DOI: 10.1007/s00226-008-0198-1 
Laine, K., Belt, T., Rautkari, L., Ramsay, J., Hill, C. A. S., and Hughes, M. (2013a). "Measuring the thickness swelling and set-recovery of densified and thermally modified Scots pine solid wood," Journal of Materials Science 48(24): 8530-8538. DOI: $10.1007 / \mathrm{s} 10853-013-7671-4$

Laine, K., Rautkari, L., Hughes, M., and Kutnar, A. (2013b). "Reducing the set-recovery of surface densified solid Scots pine wood by hydrothermal post-treatment," European Journal of Wood and Wood Products 71(1), 17-23. DOI: 10.1007/s00107012-0647-2

Laine, K., Segerholm, K., Walinder, M., Rautkari, L., and Hughes, M. (2016). "Wood densification and thermal modification: hardness, set-recovery and micromorphology," Wood Science \& Technology 50(5), 1-12. DOI: 10.1007/s00226016-0835-Z

Li, H., Jiang, X., Ramaswamy, H. S., Zhu, S., and Yu, Y. (2018). "High-pressure treatment effects on density profile, surface roughness, hardness and abrasion resistance of paulownia wood boards," Transactions of the ASABE 61(3), 1181-1188. DOI: $10.13031 /$ trans. 12718

Mantanis, G., Young, R. A., and Rowell, R. M. (1994). "Swelling of wood," Wood Science and Technology 28(2), 119-134. DOI: 10.1007/BF00192691

Navi, P., and Heger, F. (2004). "Combined densification and thermo-hydro-mechanical processing of wood," MRS Bulletin 29(5), 332-336. DOI: 10.1557/mrs2004.100

Navi, P., Pittet, V., and Plummer, C. J. G. (2002). "Transient moisture effects on wood creep," Wood Science and Technology 36(6), 447-462. DOI: 10.1007/s00226-002$0157-1$

Saifouni, O., Destrebecq, J.-F., Froidevaux, J., and Navi, P. (2016). "Experimental study of the mechanosorptive behaviour of softwood in relaxation" Wood Science and Technology 50(4), 1-17. DOI: 10.1007/s00226-016-0816-2

Skyba, O., Schwarze, F. W. M. R., and Niemz, P. (2009). "Physical and mechanical properties of thermo-hygro-mechanically (THM) - densified wood," Wood Research 54(2), 1-18.

Trenard, Y. (1977). "Study of isostatic compressibility of some timbers," Holzforschung 31(5), 166-171. DOI: 10.1515/hfsg.1977.31.5.166

Yu, Y., Ge, L., Ramaswamy, H. S., Wang, C., Zhan, Y., and Zhu, S. (2016). "Effect of high pressure processing on moisture sorption properties of brown rice," Drying Technology 34(7), 783-792. DOI: 10.1080/07373937.2015.1077457

Yu, Y., Jiang, X., Ramaswamy, H. S., Zhu, S., and Li, H. (2018). "Effect of highpressure densification on moisture sorption properties of paulownia wood," BioResources 13(12), 2473-2486. DOI: 10.15376/biores.13.2.2473-2486

Yu, Y., Zhang, F., Zhu, S., and Li, H. (2017). "Effects of high-pressure treatment on poplar wood: density profile, mechanical properties, strength potential index, and microstructure," BioResources 12(3), 6283-6297. DOI: 10.15376/biores.12.3.62836297

Zhang, H., Hu, B., and Shao, Z. (2010a). "Stress-strain relationship with compression of poplar," Journal of Anhui Agricultural University 37(4), 665-668.

Zhang, W. B. (2010b). "Moisture recovery effect of mechano-sorptive creep in wood," Journal of Harbin University of Science and Technology 15(5), 6-9. 
Zhu, S., Lin, S., Ramaswamy, H. S., Yu, Y., and Zhang, Q. (2017). "Enhancement of functional properties of rice bran proteins by high pressure treatment and their correlation with surface hydrophobicity," Food and Bioprocess Technology 10(2), 317-327. DOI: 10.1007/s11947-016-1818-7

Article submitted: July 27, 2019; Peer review completed: October 19, 2020; Revised version received: January 22, 2020; Accepted: January 24, 2020; Published: February 26, 2020.

DOI: $10.15376 /$ biores.15.2.2691-2707 